\title{
SOILS OF THE BAY OF PLENTY
}

H. S. GIBBS, Soil Bureau, Wellington, and W. A. PULLAR, Soil Bureau, Whakatane.

The Bay of Plenty is a crescent-shaped strip of land facing northward into the Pacific Ocean between East Cape and Coromandel Peninsulas. These two peninsulas are the coastal ends of two high ridges that are more than 100 miles apart across the Bay of Plenty but converge southward at right angles. The triangular area between the two ridges was a crustal depression in which a very active zone of volcanism developed, and during the Quaternary, lava, pumice, ashes, and dust were erupted at many different times and places. The lava spread out in flattish sheets that form a series of plateaux rising in irregular steps towards the Taupo district. There is no clear topographic division for the southern boundary of the Bay of Plenty district, and for purposes of this paper the district is the watershed of the streams and rivers draining into the Bay of Plenty between Waihi Beach on the west and Waihau Bay on the east. The headwaters of the Rangitaiki, Whakatane, and Motu Rivers are excluded, as they extend deeply into adjacent districts.

\section{Volcanic Ash Showers}

The soils of the Bay of Plenty are derived largely from volcanic ash and lapilli deposited in six' series of showers (Fig. 1). The latest eruption occurred in 1886 when Rotomahana ash and Tarawera lapilli were spread over lands east of Rotorua. Rotomahana ash is a grey sand and silt consisting of thermally altered ihyolite which had accumulated on the bed of Lake Rotomahana. Tarawera lapilli are black scoria and cinders ejected from Mt. Tarawera in an easterly direction and the map (Fig. 1) shows where thicknesses greater than 3 in. are found today. Shallow deposits were reported as far east as Gisborne. About 1300 A.D. Mt. Tarawera erupted pumice sands called Kaharoa ashes and traverses show two sets of deposits apparently from eruptions in opposite directions. One set towards the north west has its 3 in. boundary on the outskirts of Tauranga; the other and larger set extends south-eastward past Waikaremoana towards Wairoa. About 200 A.D. huge eruptions of pumice from vents about Lake Taupo covered the central area of the Bay of Plenty with a white sand and fine gravel. These Taupo ashes were subsequently buried by Kaharoa ashes except east of Whakatane and south of Rotorua. Below the Taupo ashes and emerging beyond their 3 in. boundary is a series of yellow sandy pumice deposits called Whakatane and 


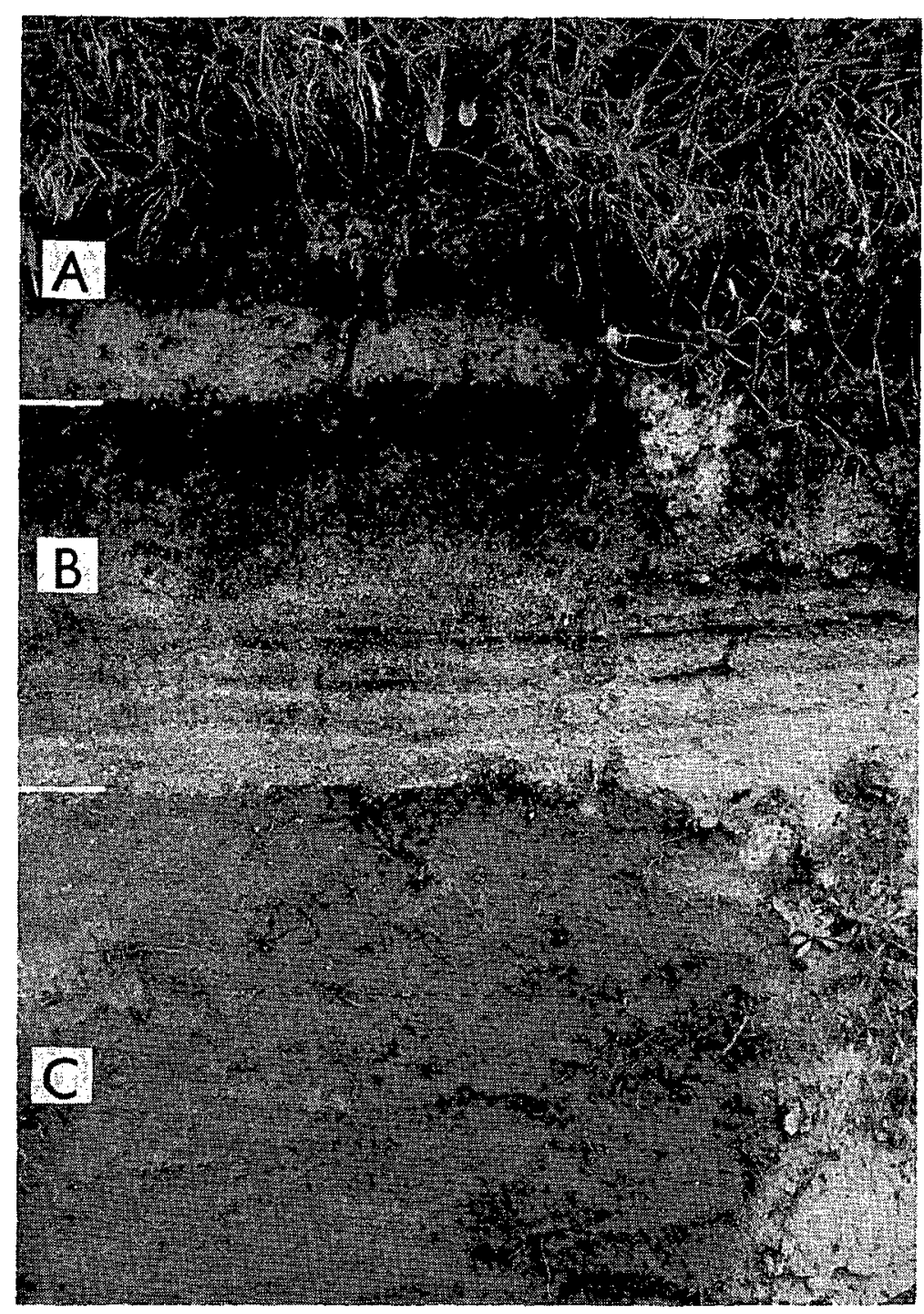

Soil profile on ash beds of Bay of Plenty: A, O-8 in., Rotomahana mud; B, 8-27 in., buried soils from Kaharoa ash; C, 27 in. plus, buried soil from Whakatane ash 
Waihi ashes named after localities where they were first recognised. Whakatane ashes are the uppermost deposits and estimated to be between 3,000 and 4,000 years old. They are more sandy and less silty than Waihi ashes, which are more weathered and considered to be about 8,000 to 10,000 years old, The two series of showers are shown together on Fig. 1 because the Whakatane ash is less than 12 in. thick where it is soil-forming and profiles include much material from Waihi ashes. Waihi ashes in turn cover older ash beds which may be seen in deep road cuttings at Waihi Beach, Tauranga, Whakatane, Matawai, and north of Waihau Bay. Black and dark brown bands exposed in these cuttings usually indicate buried soils formed in the intervals between ancient eruptions. Hence the district has a long history of periodic smothering by volcanic ash.

On river flats, peat swamps, and sand dunes that have accumulated since the latest series of showers to cover the area, the mineral constituents of soils are derived chiefly from the volcanic material eroded off the hills and deposited by the streams.

\section{SOILS}

These surface materials are converted into soils through the continual action of climate, plants, and soil organisms. At altitudes below about 800 to $1,000 \mathrm{ft}$ the mild, humid climate (av. temp. $56^{\circ} \mathrm{F}$, av. rainfall 60 in.) is very favourable to rapid and almost continuous growth of plants. This means rapid circulation of nutrients to assist the maintenance of soil fertility. Moisture limitations on plant growth are not common and occur mainly on very sandy soils near the coast and gravelly soils of lowland terraces and flats. In inland basins and on uplands above $800 \mathrm{ft}$ the climate is cooler (av. temp. $53^{\circ} \mathrm{F}$ ), generally wetter (up to $80 \mathrm{in}$. annually), rates of mineral and organic decomposition are slower, and intensity of leaching is greater. Hence the soils tend to be poorer and the annual growth of plants is less. For example, farms must be larger than on coastal lowlands to carry the same number of livestock. All these differences are shown in the pattern and potential uses of the soils. The following description is compiled from maps and reports of surveys made in the district by A. C. S. Wright, C. G. Vucetich, D. Cross, J. D. Raeside, and the writers.

The soils can conveniently be described in four divisions (Fig. 2) :

1. Pumice soils and yellow-brown loams

2. Rotomahana and Tarawera soils

3. Recent soils of lowland flats and dunes

4. Steepland soils. 


\section{Pumice Soils and Yellow-brown Loams}

The pumice soils and yellow-brown loams are light, friable soils covering all of the undulating, rolling, and hilly lands outside the boundaries. of the deposits from the Rotomahana-Tarawera eruption in 1886. They are derived from the collective deposits of Kaharoa, Taupo, and Whakatane-Waihi ashes. Soils derived from deep Kaharoa ashes are sands; those from deep Taupo ashes are silty sands to sandy silts; those from Whakatane Ashes are loamy sands to sandy loams; and those from Waihi ashes are sandy loams to silt loams, Under a similar climate near the coast subsoil colours grade from pale grey to pale yellow to brownish yellow to yellowish brown on the respective ashes. These differences of texture and colour are principally a consequence of increasing age and degree of weathering of the deposits. Soils from deep Kaharoa and Taupo ashes have visible pieces of unweathered pumice and are classed as yellow-brown pumice soils, whereas in soils from Whakatane-Waihi ashes pieces of unweathered pumice are rarely seen and they are classed as yellow-brown loams.

Each series of ash beds has a sequence' of soils, called a suite, developed by differing conditions of climate, vegetation, or. slope. An excellent illustration of a suite is obtained from examination of soils developed from deep Kaharoa ash along a sector southward from Te Puke or Tauranga. At the northern end is Paengaroa sand formed under fern and coastal fores! and having a topsoil of 6 in. of black very friable sand over 5 in. of brown loose sand grading into pale brown to white coarse sand. Base saturation is 60 per cent, indicating a weakly leached soil. Five miles south --of the Tauranga-Whakatane highway there is a gradual change of profile to $7 \mathrm{in}$. of dark brown friable sand over 4 in. of dark reddish brown loose sand grading into brown to yellowish brown coarse sands. This soil formed under broadleaf-podocarp forest is classified as Oropi sand. The rainfall is higher (60 in.) and 'the base saturation of 40 per cent shows the soils to be more leached than nearer the coast. Ten miles further south, where annual rainfalls rise to 80 in. and average temperatures are lower with increasing altitude, the soils have 3 in. of very dark brown friable sand over 3-4 in. of very pale brown loose sand over dark -reddish brown firm sand and coarse sand. These soils are classified as Kaharoa sand developed under rimu forest and the base saturation of less than 20 per cent Shows they are very strongly leached.

Similar changes in physical and chemical properties occur with soils of the Taupo and Whakatane-Waihi suites, details of which are given in Soil Bureau Bulletin 5 (Soil Bureau 1954). For pastoral farming the less strongly leached members of each suite 


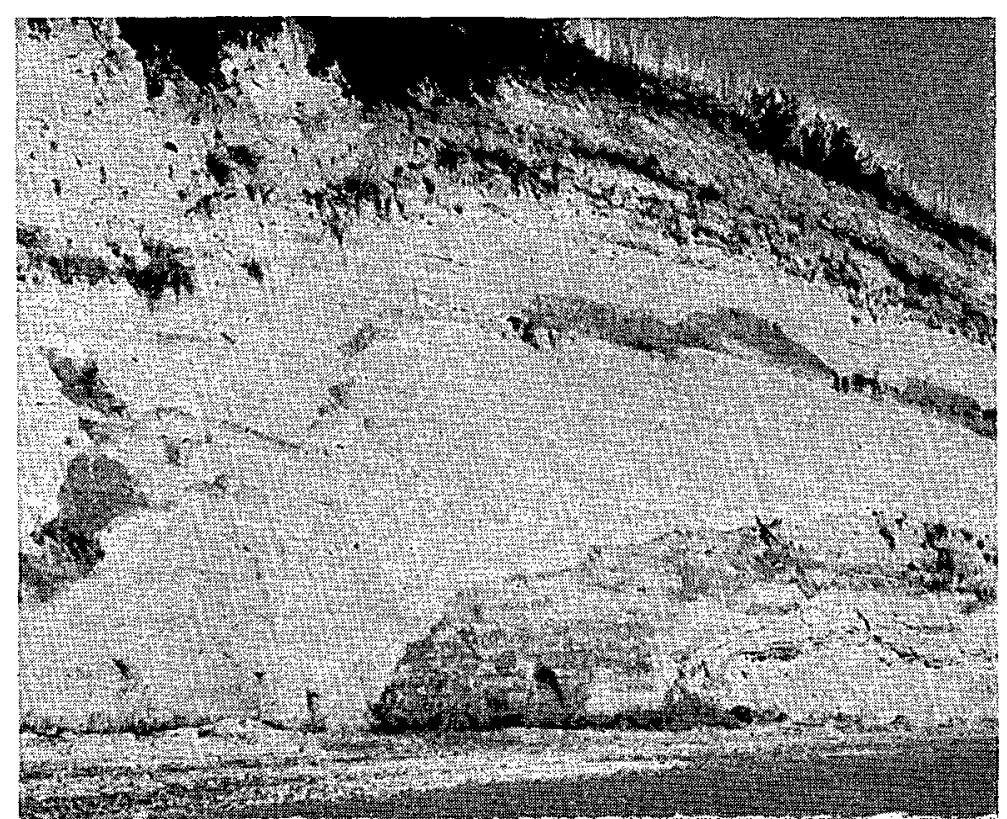

Ash beds in a cutting on the Whakatane-Ohope road. Dark bands between ash' beds indicate buried topsoils developed between ancient eruptions.

can be classified together as soils capable of maintaining highly productive pastures. With heavy topdressing the more strongly leached members of the suites will also grow high-quality pastures, but. their annual productivity is limited by the cold, wet winters and generally cool climate. For this reason they have a lower rank (class 2) for potential pastoral use.

All of the pumice soils and yellow-brown loams of the Bay of Plenty have rapid drainage, which is a decided advantage in a district of well distributed high rainfall. However, in coastal regions dry periods of two to three weeks may occur and on Paengaroa and Ohinepanea soils derived from 10 to 15 in. of, Kaharoa ashes pastures wilt badly. Such droughty soils are also included in soil potential class 2 .

\section{Allophane}

An outstanding feature of all these soils is their content of the clay mineral allophane. This clay is in the form of tiny particles only one millionth of an inch in diameter (Fieldes 1955). A mass of particles of this minute size has a huge surface area for a small volume; 'an ounce of this clay has been calculated to have a total surface area of more than two acres. This surface acts as a huge sponge for organic matter and explains the figures of 10 to 20 per cent of organic matter in topsoils of yellow-brown loams. 
In absorbing organic matter the allophane absorbs phosphorus, which is also liable to combination with the free aluminium and iron in the soils. This phosphorus is not lost but is held in a slowly available form inadequate for pastoral growth. Hence, although chemical tests may reveal high phosphorus values, this does not mean that further topdressing is not needed. Recommendations of quantities of fertiliser and times of application may be obtained from farm advisory officers at Tauranga and Whakatane.

Allophane clays in the soils are indirectly responsible for the need to apply potash. Some potassium may be absorbed on the surface of the clay, but it is easily washed off by water trickling through the soil. In soils of Gisborne, Hawke's Bay, and Manawatu lowlands most of the clay is 10 to 100 times larger than allophane and has a platy form. Potassium shelters in between the plates where it is protected against loss by solution yet is accessible to plant roots. Hence soils in areas outside the zone of volcanic ash such as Manawatu and Wairarapa generally have a lower requirement for potassium than yellow-brown loams. The amount of allophane is high in soils from Whakatane-Waihi ashes, moderate in soils from Taupo ashes, and low in soils from Kaharoa ashes, and the requirement for potassium is expected to decrease accordingly.

These chemical handicaps of allophanic clays are compensated by advantages derived from their physical properties. They are not sticky and, once moist, they absorb large amounts of water without much swelling. If the yellow-brown loams did not have this clay they would have similar drainage problems to those of the gumlands of North Auckland or the pakihis of Westland. The friability and free draining properties of the pumice soils and yellow-brown loams are a very desirable virtue in soils used for grazing in a wet climate.

\section{Soil Fertility}

The volcanic ashes of the Bay of Plenty are higher in silica and lower in metallic elements such as cobalt, nickel, copper, iron, vanadium, calcium, and magnesium than average sedimentary rocks. Moreover, and especially in the pumice soils, weathering is at an eariy stage and supplies of elements to plant roots are derived mainly from the least stable minerals. Available aluminium and iron are generally high, whereas available cobalt, nickel, vanadium, or boron may be low, due either to slow decomposition of a mineral or partial fixation by free aluminium or iron. Hence pumice soils and yellow-brown loams may be unable to meet demands for all nutrients required by rapidly growing plants. For 
example, soils from Kaharoa and Taupo ashes do not supply enough cobalt to support healthy cows and sheep. This direct deficiency of cobalt inherited from rhyolitic pumice is not found on Rotomahana or Tarawera soils. Soil and pasture analyses have shown that in the pumice soils and yellow-brown loams the level of copper is just enough for pastoral growth and animal health; but with liming or applications of molybdated superphosphate the levels of molybdenum in the grasses rise and lead to disorders in stock health unless copper is supplied to reduce the $\mathrm{Mo} / \mathrm{Cu}$ ratio in the pastures. This is an example of an indirect deficiency pro-. duced by upsetting the balance of nutrients in the soils. Another example is the likely development of magnesium deficiency by frequent topdressing with potash. Shifting of nutrient balances is much easier in pumice soils than in soils of greater weathering or higher clay content, but is no reason for making less use of them. Farmers should watch for symptoms of unthrifty plants or animals and refer the evidence to the local farm advisory officer. If he does not already know the appropriate treatment, he will initiate research to find out what element or elements are concerned.

The numerous and extensive areas of pumice soils and yellowbrown loams on undulating lands around the coast of the Bay of Plenty are an explanation for the large Maori population here when the district was visited by Captain Cook and later explorers. The light, friable, and warm soils were suitable for the subtropical plants such as kumara that they brought to New Zealand and for the primitive implements that they had. N. H. Taylor (1958) notes that the soil derived from a combination of coarse sand from the Kaharoa ash over sandy loam from Whakatane ash. is an almost perfect kumara soil from a physical point of view and may have inspired the additions of coarse textured materials 'to surface soils in other districts. Large areas of pumice soils and yellowbrown loams are still owned by Maoris and with the advantages of modern fertilisers they could make the Bay of Plenty a populous. and prosperous centre of Maori life.

\section{Rotomahana and Tarawera Soils}

Rotomahana and Tarawera soils are derived from the materials erupted in June 1886. Since eruption these, materials have developed shallow soils with properties differing mainly with the texture of the deposits and their thicknesses. Areas south of Mt. Tarawera have recently been examined and mapped by Messrs Vucetich and Cross of Soil Bureau and detailed descriptions of the soils will be included in the bulletin on the Waiotapu Sheet.

Rotomahana soils consist mainly of a grey structureless sandy loam with a 2 to 4 in. surface layer of brown friable sandy loam. 


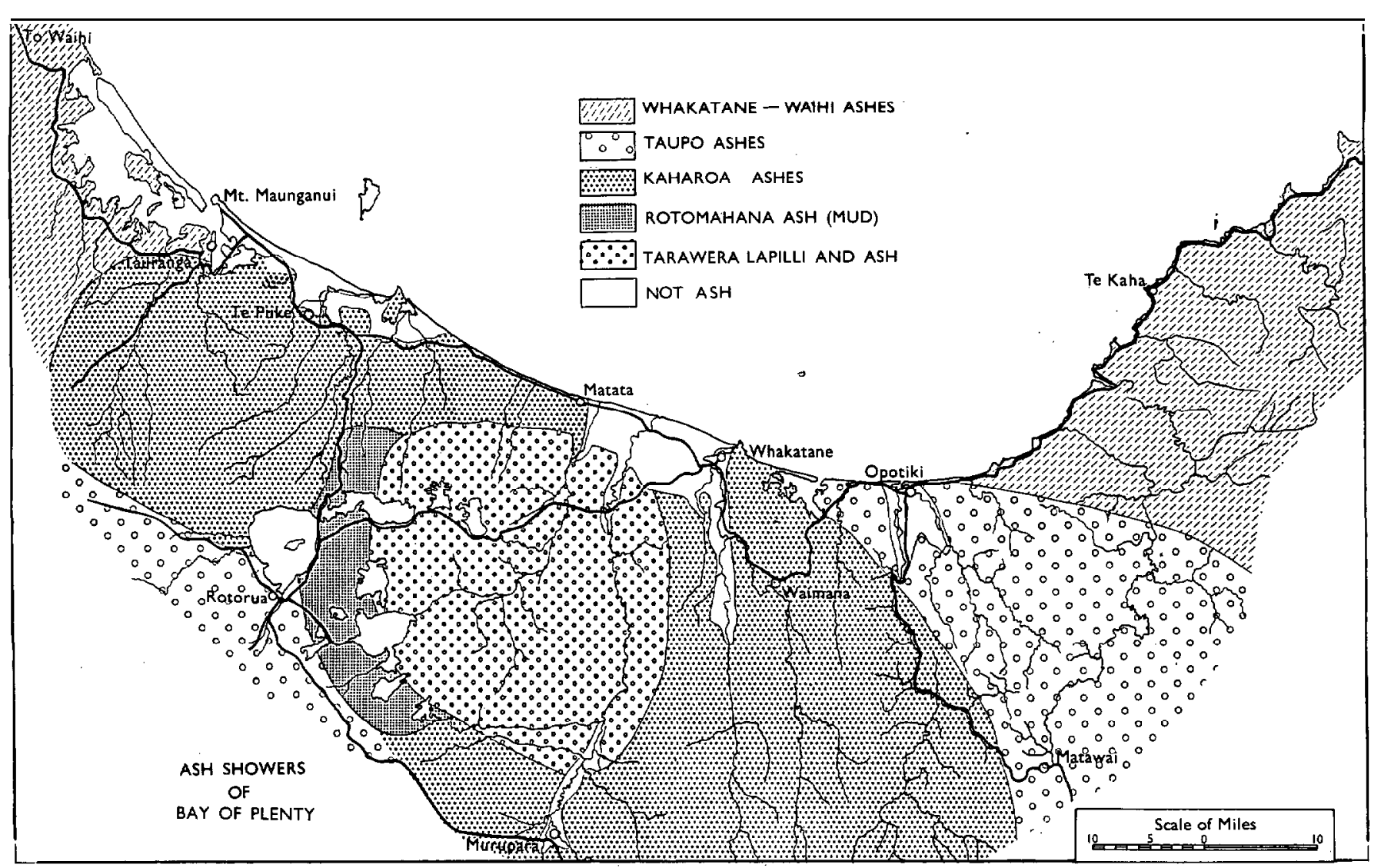




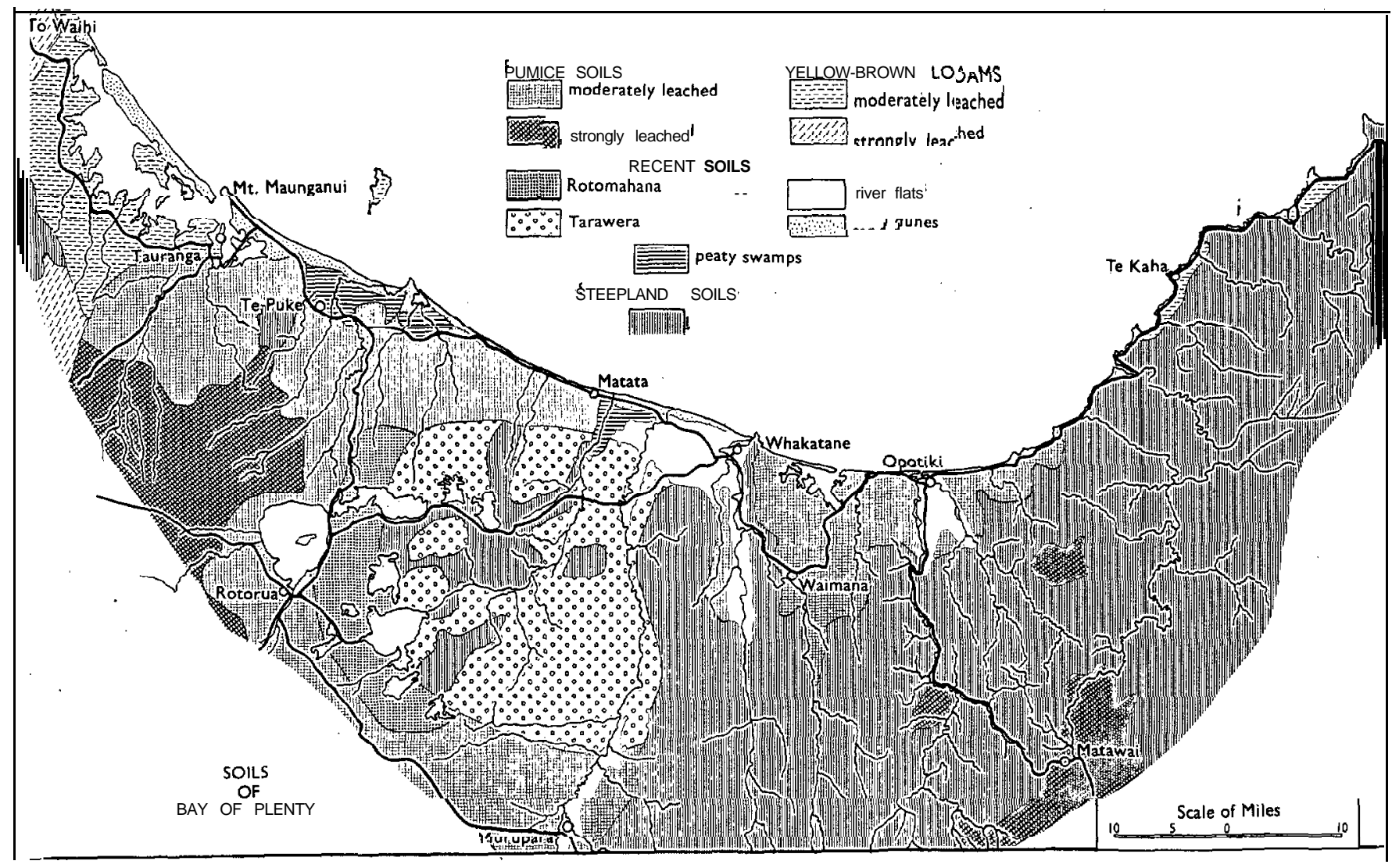




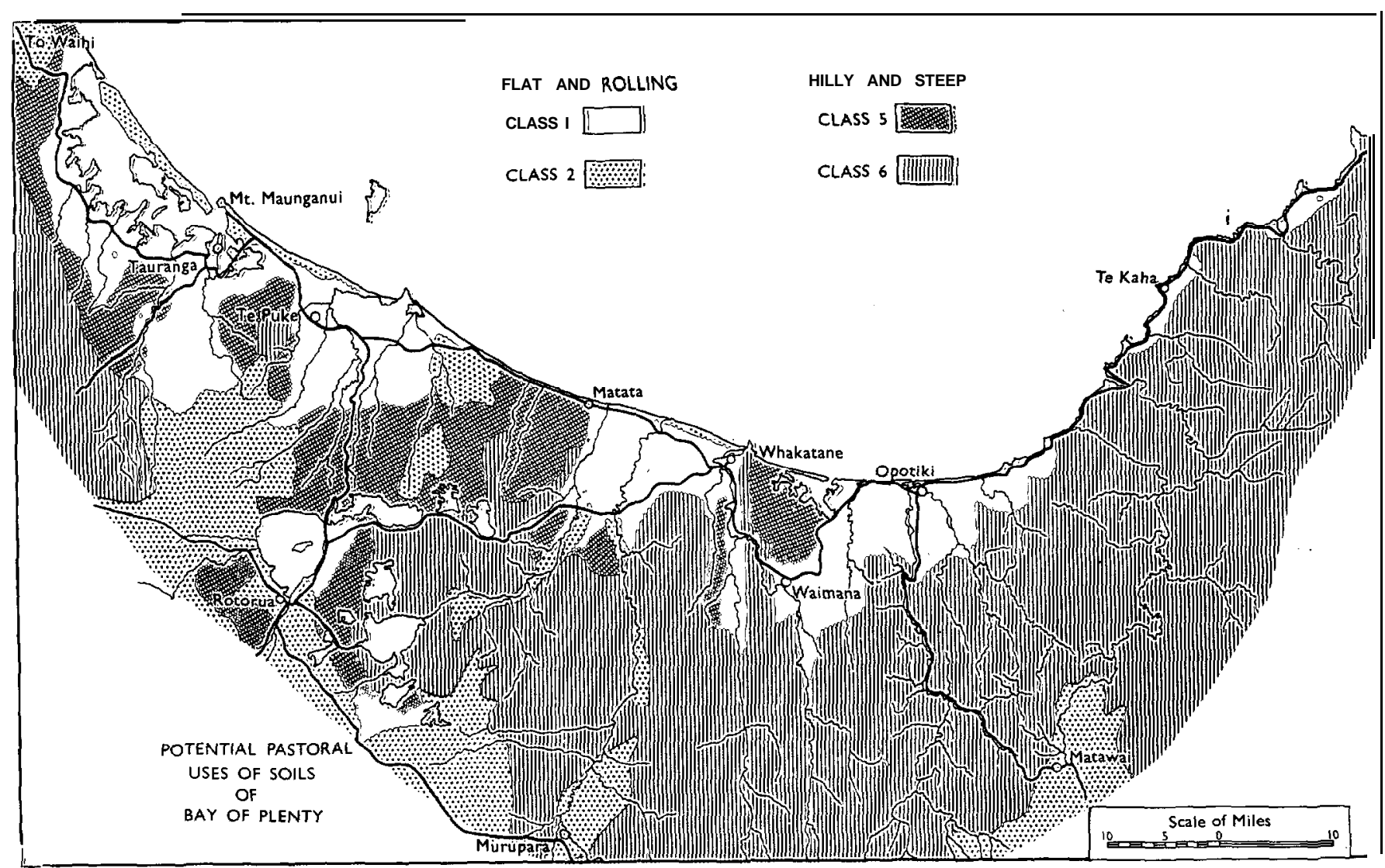


Some small basaltic stones occur in the soil, but they have not yet weathered sufficiently to contribute useful amounts of nutrients. In the Waimangu Valley small areas of silt loam and clay loam textures are found. According to analyses the Rotomahana soils are slightly to moderately acid and well supplied in plant nutrients except phosphorus. Thus they are richer than the pumice soils and with phosphates will grow excellent pastures for dairying. Hilly lands near Lake Rotomahana have soils with a coarse sandy texture and containing many stones. After the eruption when the surface was bare it was eroded into razorbacked ridges which combined with low moisture make these hilly lands unsuited to pastoral farming. Rotomahana soils cover 32,000 acres, of which 50 per cent is ploughable and the remainder hilly. They occupy a strip of land west of Mt. Tarawera and to the eastern edge of Lake Rotorua.

Tarawera soils are gravelly sands approximately 24 in. thick on the lower slopes of Mt. Tarawera and decreasing rapidly to north and south but slowly eastward to Te Teko (Fig. 2). The area with ash thicker than 3 in. is about 220,000 acres of which only 30 per cent is ploughable land. Although largely raw basaltic fragments, the soils have a moderate content of mineral nutrients derived from small amounts of fine rhyolitic and basaltic materials. But drainage is very rapid and the wide and frequent fluctuations of moisture makes pastures difficult to establish and maintain. Where the soils are shallow and many roots can reach the moist buried topsoil, good pastures for dairying have been obtained using superphosphate topdressing. Like the sand soils from Kaharoa ash they can be stocked heavily in winter without problems of puddling. Where the Tarawera soils are more than 6 in. deep the combined effects of frequent low moisture and rapid decomposition of organic matter are serious limitations to pastoral farming and the lands are better used for forestry.

\section{Recent Soils of Lowland Flats and Dunes}

This division includes a wide range of soils occurring in valley bottoms and low lying lands bordering the coast. Rates of drainage of the soils and protection from flooding are the chief factors determining potential uses.

On river flats the soils are mainly deep friable loams, sandy loams, or loamy sands moderately well supplied in all plant nutrients. Near stream channels where drainage is good the soils are suited to a wide variety of crops or to high-producing pastures. In basins away from, stream channels or on flats bordering hillsides slow drainage is the principal handicap to many uses and to high yields. Surfaces tend to be hard in summer and .very soft in wet 
periods, but with channel or tile drains the soils can be used for some crops or for pastures with rotational grazing on adjacent pumice soils or beachlands.

Coastal lands consist of a succession of sand ridges and peaty hollows generally parallel to the coastline. The sand ridges represent stages in the advance of the coastline produced by the continual supplies of alluvium carried down by the rivers. The older ridges have a shallow mantle of Taupo and Kaharoa ashes. The sand soils are moderately well supplied in plant nutrients and their usage is limited by the rapid drainage and liability to drought. Their drainage and firm surface in winter make them very suitable for grazing cows from farms on the wetter soils of the lowlands. At Tauranga and Whakatane the sand soils are the most suitable land for expansion of the towns,

Peaty soils occur in swamplands either between sand ridges or between sand ridges and cliffed edges of terrace lands. They are dark brown peaty loams containing shallow layers of volcanic ash from Tarawera, Kaharoa, or Taupo eruptions as well as some alluvium from adjacent rivers. The soils are potentially fertile but require drainage and protection from flooding. Unfortunately the lands are mainly about sea level and drainage requires pumping. Where this has been done on the Rangitaiki Plains excellent pastures for dairying have been established. Similar results could be expected near Te Puke and Papamoa if flooding by rivers and streams can be prevented.

\section{Steepland Soils}

Steepland soils occupy $1,200,000$ acres, which is more than half the area of the region. On steep slopes the soils consist mostly of 6 to 9 in. of brown to yellowish brown sandy loam derived from mixed volcanic ash over the underlying rocks. Deep ash deposits occur in some shallow valleys and on broad ridges. In central and western portions of the district the underlying rocks are hard rhyolite with little or no weathered material between rock and volcanic ash. This sharp junction is a plane of weakness against slip erosion which exposes hard rock on which soil formation is extremely slow. These steeplands are best retained in protection forest for conservation of water supplies for the lowlands.

In the eastern half of the district, where steeplands dominate the soil pattern, the underlying rocks are folded sandstones and argillites (greywacke) that have weathered to produce a 6 to 12 in. layer of stony loam between volcanic ash and the hard rocks. The native forest has been cleared from many slopes, but the fertility is moderate to low and pastures have been invaded rather 
vigorously by fern' and shrubs. Slip erosion increases under grazing, but exposed surfaces are soon covered by plants and there is not the continued erosion of the rock materials that is so serious in parts of Gisborne district. Where farms have sufficient pumice soils or yellow-brown loams for their main pastoral requirements, areas of adjacent steepland soils may be maintained in pasture, but otherwise are best retained as forestry land. Timber production is likely to equal or exceed the value of animal farming and mean much less risk of flooding the lowland flats.

The surveys and analyses of soils of the Bay of Plenty all show that the district has a wide variety of soils with differences important to land use. Though there are no very rich soils, neither are there eny very poor ones. From a grassland point of view four classes of soils can be recognised, two on land of ploughable slope and two on moderately steep and steep lands (Fig. 3).

Soils on ploughable slopes that can be converted to highly productive pastoral land (class 1) include:

(a) Loamy soils of the river flats $(75,000$ acres). These have moderate natural fertility and with little topdressing and simple drainage where necessary will give high yields of pasture or crops. Economically they are the most efficient soils for use in intensive farming and should be conserved for that purpose.

(b) The peaty soils of coastal swamps (50,000 acres). Under natural conditions productivity is low but can be raised with drainage, flood protection, and application of fertilisers. Excellent results have been obtained from farming these peaty soils in conjunction with free-draining pumice soils and shallow Tarawera soils,

(c) The 16,000 acres of Rotomahana soils with application of fertilisers to assist the development of topsoils under pasture.

(d) The moderately and strongly leached pumice soils and yellow-brown loams of coastal regions $(250,000$ acres). The excellent drainage and friability of these soils provide ideal physical conditions for pasture growth, which thrives when fertilisers are added to supply deficient nutrients. Nutrient balances are easily changed and careful selection of fertilisers is necessary.

The soils in class 1 occupy aproximately 400,000 acres, which is about 16 per cent of the total area.

The remaining soils on land of ploughable slope have moderate limitations to production as pastoral land but less so for forestry. They also cover approximately 400,000 acres. Included in class 2 are: 
(a) sand soils of coastal dunes on which plants suffer from drought (40,000 acres),

(b) coarse sand soils from Kaharoa ash in areas near the coast where there are periods of three to four weeks without rain and where moisture is deficient for plant growth $(5,000$ acres),

(c) gravelly soils from Tarawera lapilli (70,000 acres) in which the moisture limitations of (a) and (b) are more severe, and

(d) the pumice soils and yellow-brown loams of high plateaux and inland basins where frosts and a wide range of temperature or drought limit total plant growth $(285,000$ acres).

On hilly and steep lands all of the soils require fertilisers to maintain productive pastures. ${ }^{*}$ The soils requiring fertilisers less frequently, also not liable to serious erosion, are shown in class 5 and include:

(a) moderately and strongly leached pumice soils and yellowbrown loams on hilly lands (250,000 acres). Deposits of volcanic ash on these slopes tend to have good moisture conditions below the surface, and

(b) Rotomahana and shallow Tarawera soils on hilly land not dissected into razorbacked ridges (30,000 acres).

Careful management of pastures on these soils is essential to obtain satisfactory benefit from fertilisers. Soils of class 5 occlpy 280,000 acres, which is 12 per cent of the district.

The other soils on moderately steep and steep lands either require topdressing annually or are susceptiblc to serious erosion. They include all steepland soils and coarse sandy and gravelly soils on hilly land. These soils total $1,320,000$ acres, which is about 56 per cent of the district. They are shown as class 6 and are generally considered to be more suited to forestry than to pastoral uses. Areas of steeplands bordering class 1 soils may hold fair quality pastures under rotational grazing. Allowing 6 per cent for such use gives a pastoral picture from the soil point of view of a district half unsuited to pastoral farming. On the other half there is 400,000 acres of potentially high quality pastoral land and about 750,000 acres of moderate quality pastoral land on which timber production is a suitable alternative. Most of the soils had low natural fertility, but they respond rapidly and well to fertilisers and management. Give the soils that right treatment and the district will live up to its name of the Bay of Plenty.

* Classes 3 and 4 have not been used in the Bay of Plenty. Class 3 is ploughable land with serious limitations to pastoral use. Class 4 is hilly land that will maintain pasture without topdressing and serious erosion. 


\section{REFERENCES}

Fieldes, M. 1955: Clay Mineralogy of New Zealand Soils, Part 11: Allophane and related mineral colloids. N.Z.J.Sci.Tech. B, 37: 337-50. N.Z. Soil Bureau 1954: General Survey of the Soils of North Island, New Zealand. N.Z. Soil Bur. Bull. 5, 286 pp.

Taylor, N. H. 1958: Soil Science and New Zealand Prehistory. N.Z.Sci.Rev., 16: pp. 71-79.

Wells, N. 1960: Total Elements in Topsoils from lgneous Rocks: An Extension of Geochemistry. J.S.Sc., 11:409-24.

\section{DISCUSSION}

Q. (P. D. Sears): Can Mr Gibbs visualise some of the steepland soils covered by protective forestry to enable other parts to be utilised for grassland?

A. With aerial topdressing it is possible to utilise steep slopes up to an altitude of $1,200 \mathrm{ft}$. However, it is essential to look after the lower flats and prevent flooding. The district is liable to high intensity rains and until a permanent close cover of pasture is possible, it is preferred that most of the steepland be classified generally unsuitable for pastoral use.

Q. (Grange, Katikati) : Would the moderately leached soils in the Katikati area be low in minor elements?

A. This soil is leached of the more soluble elements-calcium, magnesium and potash. The less soluble elements such as copper or molybdenum are not so leached and may be built up. Minor element requirements of plants are not known exactly and deficiencies can crop up without warning either in pasture or livestock.

Q. (I. L. Elliott, Rukuhia): Would Mr Gibbs comment on the cobalt status of the various showers?

A. Soils derived from Kaharoa and Taupo showers are deficient in cobalt. The Waihi-Whakatane yellow-brown loams contain small amounts of cobalt and deficiencies can be expected to occur in time with intensive grassland farming and on upland hill areas of about $1,000 \mathrm{ft}$ where the rainfall is higher and leaching consequently greater. Tarawera and Rotomahana materials are high in cobalt and deposits of one inch thickness over Kaharoa ash can make the combined soils healthy for livestock.

Q. (A. Duncan): Is there a tendency for the yellow-brown loams around Whakatane to become impervious to water under farming?

A. No. They will remain free draining because they have a sandy topsoil, grass roots spread well and are able to reform the structure of the soil very rapidly, after concentrated stocking.

Q. (G. Banfield): Did I understand Mr Gibbs to say that soils are classified by their parent material in the top 3 inches?

A. Soils are classed on a complete profile, and this is related to the parent material. In most soils from volcanic ash the parent materials are a mixture of ashes and only those showers contributing 3 inches or more have been named. This arbitrary limit is due to practical difficulties of recognising less than 3 inch deposits particularly in topsoils where plants, earthworms and cultivation blend the surface materials together. 